Agro-Science Journal of Tropical Agriculture, Food, Environment and Extension Volume 14 Number 1 January 2015 pp. $1-17$

ISSNIII9-7455

\title{
ANALYTICAL OVERVIEW OF AGRICULTURAL CONDITIONS IN NIGERIA
}

\author{
Asadu C L. A. ${ }^{1^{*}}$ and A. N. Asadu ${ }^{2}$ \\ ${ }^{1}$ Department of Soil Science, University of Nigeria, Nsukka, Nigeria \\ ${ }^{2}$ Department of Agricultural Extension, University of Nigeria, Nsukka, Nigeria \\ *E-mail: charlesasadu@yahoo.com (Corresponding author)
}

\begin{abstract}
:
Nigeria is a tropical country with a population of over 135 million. Over $70 \%$ of the population are engaged in agriculture as their primary source of income and despite low investment by the previous governments, it still contributes over 39\% of the Gross Domestic Product (GDP). The large land mass, good soil and climatic conditions favour the growth of various crops during the year and the rearing of many animals. Food shortage is a major challenge to the present government apart from political disputes, disturbances in oil producing states in the Niger delta and poor funding of many other sectors particularly agriculture and education. Agricultural (including extension) policies over the years have been elaborate and attractive in most cases but they are only so on papers in the shelves in the government offices. Prospects for improvement and sustainable agricultural productivity exist because of the country's endowment in natural resources especially abundant uncultivated arable lands, favourable climate and soils that are improvable as well as large human labour. These resources if well integrated can help boost agricultural production in the country. The present status demands adequate and prompt attention by all three tiers of government in the country viz: Local, State and Federal governments.
\end{abstract}

Key words: Agriculture, natural resources, food shortage, government policies

\section{INTRODUCTION}

\section{Geographical Conditions in Nigeria Location and landforms}

Nigeria (fig.1) is bounded in the south by the Atlantic Ocean, with limits set by Gulf of Guinea (Bights of Benin and Biafra); the inland frontiers are shared with Cameroon (east), Chad (northeast), Niger (north), and Benin (west). Separating the two segments of the coastal plain and extending to the northeast and northwest are the broad river basins of the Niger and Benue rivers. The upper reaches of these rivers form narrow valleys and contain falls and rapids. Most of the lower portions, however, are free from rapids and have extensive floodplains and braided stream channels. To the north of the Niger and Benue basins are the broad, stepped plateau and granite mountains that characterize much of northern Nigeria.

Such mountains are also found in the southwest, in the region between the western coastal plains and the upper Niger Basin. The western wedge between Abeokuta and Ibadan and the Niger Basin reaches elevations of 600 meters or more, while the extensive northern savanna region, stretching from Kontagora to Gombe and east to the border, includes extensive areas with elevations of more than 1,200 meters or more at its center.

The mountainous zone along the middle part of the eastern border, the Cameroon Highlands, includes the country's highest point $(2,042$ meters). In the far northeast and northwest, elevation falls again to below 300 meters in the Chad Basin in the far northeast and the Sokoto Basin in the north west. Much of Nigeria's surface consists of ancient crystalline rocks of the African Shield. Having been subject to weathering and erosion for long periods, the characteristic landscape of this area is extensive level plains interrupted by occasional granite mountains. These features form a major landscape type of Nigeria and of West Africa as a whole. There are also smaller areas of younger granites found, for example, on the Jos Plateau. There are rocks of sedimentary formations which overlay the older rocks in many areas. 
Analytical Overview of Agricultural Conditions in Nigeria

$\mathrm{Tr}$

topped ridges and dissected plateaux with landscape of extensive plains and no major rocky outcrops. This landscape is generally true of the basins of the Niger and Benue rivers as well as the depressions of the Chad and Sokoto basins in the far northeast and northwest of the country, respectively. The most dramatic of the sedimentary landscapes are in southeastern Nigeria, where thick sedimentary beds from the Abakaliki Uplift to the Anambra Basin have been tilted and eroded. This process has resulted in a rugged scarp land topography with eastfacing cliffs around the Udi Hills, north of Enugu, and in the area around Nanka and Agulu a landform described as a cuesta. Although relatively little of the Nigerian landscape has been shaped by volcanic episodes, there are two main areas of volcanic rock. They are found on the Biu Plateau in the northeast, extending into some localized volcanic areas along the eastern border with Cameroon, and on the Jos Plateau in the northern central part of the country.

\section{Climate}

Nigeria has tropical climate with variations especially in rainfall and temperature governed by interaction between the moist Southwest Monsoon Winds (SMW) and the dry Northeast Trade Winds (NTW). The mean maximum temperatures increase northwards from $30-32^{\circ} \mathrm{C}$ in the southern part and $33>35^{\circ} \mathrm{C}$ in the northern part. On the other hand annual rainfall and the relative humidity decrease northwards. Annual rainfall total is about $2,000 \mathrm{~mm}$ in coastal zone (in the Niger Delta it averages over $3,550 \mathrm{~mm}$ ); but ranges from only 500 to $750 \mathrm{~mm}$ in the north. The beginning of the rains is usually marked by the incidence of high winds and heavy but scattered squalls. The scattered quality of this storm rainfall is especially noticeable in the north in dry years, when rain may be abundant in some small areas while other contiguous places are completely dry. By April or early May in most years, the rainy season is under way throughout most of the area south of the Niger and Benue river valleys. Farther north, it is usually June or July before the rains really commence.

The rainfall distribution gives the country two major seasons namely the rainy and dry seasons. The period of rainy season can vary from almost ten months in some parts of extreme south near the Atlantic coast to two months in the extreme north, the reverse being the case for dry season. During the rainy season in the south, there is always a short dry spell (2-3 weeks) referred to as August break because it often occurs in the month of August every year (Asadu, 2002a). Again during the dry season red to as

Harmattan. It is a period when the atmosphere is very hazy with high obscurity to vision. There is high relative humidity $(\geq 60 \%)$ in most parts of the south during greater parts of the year February - November while in most parts of the north high humidity is only experienced from June to September. The remaining periods of the year in both regions fall within the dry season.

The various climatic periods found in the country provide opportunities for crop production at different times of the year. However, the variability of the climatic elements especially rainfall and the occurrence of the august break and harmattan tend to frustrate the efforts of the farmers in scheduling their farming activities. Future researches need to address these changes vis-avis farmers' agricultural activities.

As in most of West Africa, Nigeria's climate is characterized by strong latitudinal zones, becoming progressively drier as one moves north from the coast. Rainfall is the key climatic variable, and there is a marked alternation of wet and dry seasons in most areas. Two air masses the NTW and SMW control rainfall. The SWM is moist northward-moving maritime air coming from the Atlantic Ocean and the NTW dry continental air coming south from the African landmass, the Sahara desert. Topographic relief plays a significant role in local climate only around the Jos Plateau and along the eastern border highlands.

The peak of the rainy season occurs through most of northern Nigeria in August, when air from the Atlantic covers the entire country. Given this climatological cycle and the size of the country, there is a considerable range in total annual rainfall across Nigeria, both from south to north and, in some regions, from east to west. The greatest total precipitation is generally in the southeast, along the coast around Bonny (south of Port Harcourt) and east of Calabar, where mean annual rainfall is more than 4,000 millimeters . Most of the rest of the southeast receives between 2,000 and 3,000 millimeters of rain per year, and the southwest (lying farther north) receives lower total rainfall, generally between 1,250 and 2,500 millimeters per year. Mean annual precipitation at Lagos is about 1,900 millimeters; at Ibadan, only about 140 kilometers north of Lagos, mean annual rainfall drops to around 1,250 millimeters. Moving north from Ibadan, mean annual rainfall in the west is in the range of 1,200 to 1,300 millimeters.

The northern Guinea savanna and then the Sudan savanna zones result from the decline in the total rainfall and the length of the rainy season as one moves northwards. The Guinea savanna starts in the middle belt, or southern part 
of northern Nigeria. It is distinguished from the Sudan savanna because it has more trees an indication of more rains resulting from longer rain period whereas the Sudan savanna has few trees. The average rain period in Kano ranges from 120 to 130 days, but further north in Katsina and Sokoto it is 10 to 20 days shorter.

The mean temperatures throughout Nigeria are generally high. Characteristically, diurnal variations are more pronounced than seasonal ones. The highest temperatures experienced during the dry season is due to that rainfall moderates afternoon highs during the wet season. The variations also increase from the coast towards the north. Average highs and lows for Lagos are $31^{\circ} \mathrm{C}$ and $23^{\circ} \mathrm{C}$ in January and $28^{\circ} \mathrm{C}$ and $23^{\circ} \mathrm{C}$ in June but temperatures reach as high as $44^{\circ} \mathrm{C}$ before the onset of the rains or drop as low as $6^{\circ} \mathrm{C}$ during an intrusion of cool air from the north especially from December to February in the northern parts.

\section{BRIEFS ON LAND USE}

The concept of land has been defined as the area of the earth's surface the characteristics of which embrace all reasonably stable, or predictable cyclic attributes of the atmosphere vertically above and below this area including those of the atmosphere, the soil and underlying geology, the hydrology, the plant and animal populations, and the results of past and present human activity, to the extent that these attributes exert a significant influence on the present and future uses of the land by man (FAO ,1976). Land has also been referred to as the totality of fundamentals to our existence (Akamigbo, 1999). As found in many nations, land is used for various purposes in Nigeria. However, land use types differ from one location to another depending on the immediate needs of the government, community or individual concerned. In Nigeria, land is used for agriculture, urban development, industrial and commercial purposes in that order of decreasing importance (FDALR, 1996). The land under agricultural production is further categorized into different uses that are related to
a. forestry
b. arable crop production
c. tree crop production
d. grazing
e. fishing and tourism (national parks including sporting activities)

Table 1 presents the different proportions of land area used for different purposes in Nigeria In 1990, estimates indicated that 82 million hectares out of Nigeria's total land area of about 91 million hectares were arable. However, only about 34 million hectares (or 42 percent of the cultivable area) were being cultivated at the time. Much of this land was farmed under bush fallow, a technique whereby an area much larger than that under cultivation is left idle for varying periods to allow natural regeneration of soil fertility.

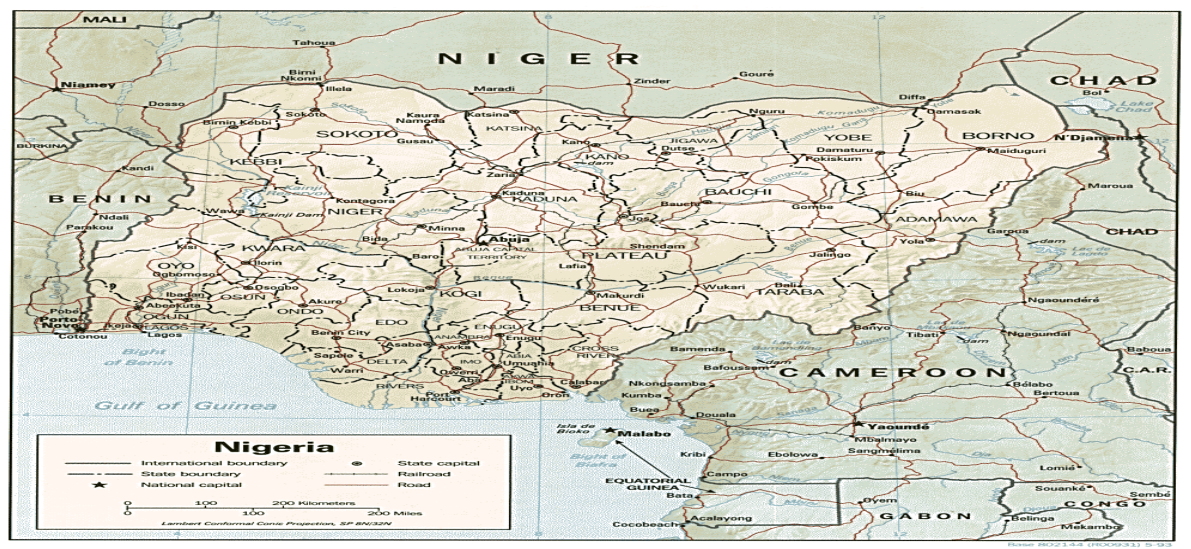

Fig1: Map of Nigeria

Table 1: Land mass distribution by use types

\begin{tabular}{|c|c|c|c|c|c|}
\hline Total area & & $923,768 \mathrm{sq} \mathrm{km}$ & & & \\
\hline $\begin{array}{l}\text { Land surface } \\
\mathrm{km})\end{array}$ & & $\begin{array}{l}\text { Water surface } \quad(s q \\
\mathrm{km})\end{array}$ & Arable/land (\%) & $\begin{array}{l}\text { Permanent } \\
\text { crop/land } \\
(\%)\end{array}$ & Others/land (\%) \\
\hline 910,768 & & $13,000 \mathrm{sq} \mathrm{km}$ & $\begin{array}{l}31.29 \\
42 \text { under cultivation }\end{array}$ & 2.96 & 65.75 \\
\hline
\end{tabular}

Sources: (Metzi, 1991, Asadu, et al. 2004] 
Another 18 million hectares were classitied as permanent pasture, but much of this land had the potential to support crops. About 20 million hectares were covered by forests and woodlands. A large proportion of this land also has agricultural potentials. The country's remaining 19 million hectares were covered by buildings or roads, or were considered wasteland.

\section{Soil Conditions}

Soils are dynamic natural bodies comprising the uppermost layer of the earth, exhibiting distinct organization of their mineral and organic components; including water and air, which formed in response to atmospheric and biospheric forces acting on various parent materials under diverse geomorphic conditions over a period of time (Yaalon and Arnold, 2000). Soil is formed by natural processes which act on factors of soil formation viz: parent material, climate, living organism, topography and time. African surfaces are among the oldest in the world; thus, the relationships between the soils and the five soil forming factors are much more complex because the land surface has undergone a series of vegetative and climatic shifts (Foth and Schafer, 1980). Generally, soil is part of the land and land degradation very often includes soil degradation. In general, the soils of most African states including Nigeria are of a poorer quality than those in other regions of the world. However, over the centuries Nigerian farmers have utilized certain agricultural techniques to cope with the shortcomings of their soils. Nigeria is yet to have a detailed practical and utilitarian soil map. Thus, description of soils of Nigeria here may be presented in two forms namely that related to geographic location or zones and that related to their genetic characteristics. These are briefly presented below.

Nigerian Soils Based On Geographic Location The major soil types or zones are generally influenced by the characteristics of the different geographic locations in the country. The dominant soils of the northern region are loose sandy soils consisting of wind-borne deposits and riverine sands, although, in areas where there is a marked dry season, a dense surface layer of laterite develops, making these soils difficult to cultivate. The soils in the northern states, however, are not subject to leaching and are therefore easily farmed. They are, however, of low fertility status and heavy fertilization is required for the soils to give meaningful yield. Southwards there are mixed soils which contain locally derived granite and loess (wind-borne deposits). The middle two-thirds of the country, the savanna regions, contain reddish, lateritic solls; they are somewhat less tertile than those of the north because they are not subject to as much seasonal drying, nor do they receive the greater rainfall that occurs in the more southerly regions. In the forest areas of the south we have the forest soils which represent the third soil zone. In this zone the vegetation provides litter which on decomposition provide humus and also protects the soils from erosion by the heavy rainfall characteristic of the zone. Although these soils can readily be leached and lose their fertility, they are the most productive agriculturally. Along the banks, coasts and floodplains are hydromorphic and organic soils, especially in areas underlain by sedimentary rocks and alluvial deposits. These are the youngest soil types and the most fertile and extensively used for rice production. The optimum productivity of most Nigerian soils depends on the management techniques adopted to manage the chemical fertility. The physical properties of most Nigerian soils are good.

\section{Genetic Description}

In this case only soil names from standard soil classification system, the USDA Soil Taxonomy is used to represent dominant soils in Nigeria (USDA, 1998). They are briefly described as follows

Ultisols The FAO/UNESCO systems map this area as ferallitic soils. In the FAO/UNESCO system the ferrallitic soils are the most extensive soils found in Africa including Nigeria (Foth and Schafer,1980). These soils are considered to be in the final stages of weathering and even kaolinite and quartz have been altered. Many are polygenetic and reflect previous as well as present environmental conditions. Generally, most of the bases are in the organic matters or the surface mineral horizon; fertility and percent base saturation decrease with depth. These soils are either heavily fertilized or managed by heavy application of organic manure or shifting agricultural method. Oxisols. The oxisols in Nigeria reflect an intensive weathering under a hot humid climate on an old level, unrejuvenated landscape. Many of these oxisols are shallow to bedrock and have developed in old eroded soils or exposed to plinthite. Intensive and continuous weathering with losses of silicates by hydrolysis, result in accumulation of sesquioxides. Oxide clay dominates the clay fraction, and the silicate clays that remain are primarily koalinitic in nature. Large quantities of iron and aluminum oxides are present. The CEC of oxisols is generally less than $20 \mathrm{cmol} / \mathrm{kg}$ soil. Base saturation is less than $40 \%$. They are very unfertile because they lack weatherable 
minerals. They are very low in total $\mathrm{P}$ and often show a high $\mathrm{P}$ fixation capacity.

Oxisols are considered the poorest soils (Foth and Schafer, 1980). In parts of the Country oxisols are mostly grown to tree crops such as rubber, cashew, and oil palm. Oxisols respond to proper management techniques, which may involve extensive use of fertilizer with particular attention to micronutrient needs. Heavy rates of lime are required to reduce aluminum toxicity.

Alfisol is widely distributed in Nigeria. Primary emphasis is placed on the presence of an argillic horizon with a high base status. They are found in grassland and savanna zones of the country. Also, kaolinite clays dominate, with 2:1 clays often present in small amounts. They have low $\mathrm{CEC}$, but the base saturation is sufficiently high $(>35 \%)$ to classify them as Alfisols. Iron concretion may be formed in the profile as a result of leaching of free iron. The reserve of weatherable aluminum is often appreciable. Agricultural potential of this soils is good. They are of moderately low fertility status but respond well to fertilizer.

Aridisols dominate the areas closest to the Sahara in the extreme northern Nigeria. These regions are too dry to be very productive. However, there is considerable nomadic grazing in those parts of the desert that receive sufficient moisture to provide grazeable vegetation.

Inceptisols and Entisols are frequently found in river valleys e.g. along rivers Niger and Zaire. These deltaic soils are classified as Tropaquepts because of their tropical climate and the poor drainage of these plains. Drainage and oxidation of these soils lead to the formation of large concentration of sulfates. The $\mathrm{pH}$ may drop to a value of 3 or less and the availability of aluminum, manganese and iron may increase to levels toxic to plants. Because of the expenses and difficulty of reclaiming these soils, they are frequently used for lowland rice or simply are wasteland.

Table 2: Comparison of the contribution of agriculture to GDP with other sectors

\begin{tabular}{lll}
\hline Sector & Contribution to GDP $(\boldsymbol{\%})$ & Sources/date \\
\hline Agriculture & 39.1 & 1998 \\
Industries & 30.5 & 2004 \\
Services & 33.3 & 2004 \\
\hline
\end{tabular}

Source: (Rosenberg, 2005)

Table 3: Major Crops grown in Nigeria by region

\begin{tabular}{|c|c|c|c|}
\hline Crop category & Southern zone & Middle belt zone & Northern zone \\
\hline \multirow{4}{*}{ Cash crops } & $\mathrm{Cocoa}^{+}$ & Beniseed & Groundnut \\
\hline & Rubber & Rubber & Cotton \\
\hline & Oil palm & $\mathrm{Cocoa}^{+}$ & Beniseed \\
\hline & & Oil palm & \\
\hline \multirow[t]{13}{*}{ Food crops } & Yam & Yam & Sorghum \\
\hline & Cassava & Cassava & Millet \\
\hline & Maize & Maize & Rice \\
\hline & Rice & Rice & Soya beans \\
\hline & Cocoyam & Cocoyam & Pigeon pea \\
\hline & Plantain & Plantain & \\
\hline & Sweet potatoes & Sorghum & potatoes \\
\hline & & Millet & \\
\hline & & Soya beans & \\
\hline & & Beniseed & \\
\hline & & Cowpeas & \\
\hline & & Pigeon pea & \\
\hline & & Sweet potatoes & \\
\hline
\end{tabular}


Vertisols These developed from basic rocks rich in ferromagnesium minerals or calcium containing rocks. They tend to be fertile but are only found in small pockets especially in fadama lands in the country. They are capable of producing a wide variety of crops including sugarcane, cotton, grain, tobacco, and fodder. Water holding characteristics and tilth of vertisols make them difficult to manage. When wet, they are sticky and puddle easily. When they are dry they are often hard and difficult to till and susceptible to shattering.

\section{Major Crops}

Generally, economic development tends to diminish the relative size of the agricultural sector or the contribution of the agricultural sector to the GDP which in Nigeria decreased from over $65 \%$ in 1959 to about $39 \%$ currently (Table 2).

The contribution of the agricultural sector increased by 3.8 percent yearly between 1983 and

1988, and the percentage of export value in agriculture grew from 3 percent in 1983 to 9 percent in 1988, although much of this growth resulted from the fall in oil export receipts. Food production also increased rapidly during the 1980s, especially after exchange-rate reform restricted food imports in 1986. The exception here was in 19983-1984 when the country experienced serious shortages resulting from drought in 1983.

The major cash crops before crude oil gained prominence in 1965 were cocoa, oil palm, rubber, cotton, groundnut or peanuts and beniseed (Table 3) with cocoa and groundnut surpassing others then. Cocoa, cotton, groundnuts, oil palm products, and rubber were the principal export crops in the 1960s and early 1970s; it is only cacao that is exported presently. With the assistance from the World Bank, the government restored cocoa production in the late 1970 s and 1980s through replanting programs and producer price supports.
The resulting increase in cocoa output (to 200,000 tons in 1988) kept Nigeria in the third place among world cocoa producers, after Ivory Coast and Ghana (Metzi 1991). The amount of each of the other crops produced presently in the country does not even meet the local demands. The major food crops by region are presented in Table 3. Many crops cut across the southern and middle belt zones eg. cassava, yams, cocoyam, rice and maize. Similarly many crops cut across the middle belt and the northern zones.

Nigeria's climate permits the cultivation of a variety of crops in a pattern that emerged in earlier centuries in response to local conditions. As in other West Africa states, rainfall is heaviest in the south, where the forests and savannas benefit from abundant precipitation and relatively short dry seasons. The staples are root crops, including cassava, yams, taro (cocoyams), and sweet potatoes. Tree crops such as cacao, oil palm, and rubber constitute the main commercial produce. Cacao, from which several beverages are made, grows mostly in the southwest. Oil palms (whose main produce is oil) predominate in the southeast and are numerous in the south-central area. Rubber production is common in south-central and southeastern Nigeria.

Smallholder farmers, who use simple production techniques and bush-fallow cultivation, and cultivate areas of one-half to two hectares, each, contribute two-thirds of farm production. In most areas, some catch (non-cash) crops such as sorghum, yams, cassava, cowpeas, millet, corn, cocoyams, sweet potatoes, and rice are grown.

Between the arid north and the moist south lies a Guinea savanna region sometimes referred to as the middle belt. This area produces staples such as yams, sorghum, millet, cassava, cowpeas, and corn, and rice which is a very important crop in some places. The middle belt's southern edge represents the lower limits of the northern graindominated economy. One of the most significant commercial crops in some parts of the middle belt is sesame (or beniseed)

Table 4: Livestock Distribution by major production zones by dominant livestock type

\begin{tabular}{lll}
\hline Region & Livestock reared & Proportion by region $(\%)$ \\
\hline Southern region & Sheep & not available \\
& Goat & not available \\
& Pigs & $\geq \mathbf{9 6}$ \\
& Poultry & not available \\
Some Tryps-resistant cattle & $\leq \mathbf{4}$ \\
& Total livestock except pigs and poultry & $\approx \mathbf{2 0}$ \\
& Sheep & not available \\
& Goat & not available \\
& Pigs & $\leq \mathbf{4}$ \\
& Poultry & not available \\
& Cattle & $\geq \mathbf{9 6}$ \\
& Horses & not available \\
& Donkeys & not available \\
& Camels & not available \\
\hline
\end{tabular}


The northern third of Nigeria, which experiences a dry season of five to seven months, during which less than twenty-five millimeters of rain falls, lies mostly in the Sudan savanna and the arid Sahel zone. There, the staples are millet, cowpeas, and a drought-resistant variety of sorghum. Corn is also cultivated, as well as rice in suitable lowland areas. The north's principal commercial crops are cotton and groundnuts.

Fadamas ( low land areas with ponded water) exist in various parts of the country but are found more in the northern zone. The soil retain a lot of water and the land is often cultivated during the dry season and grown to many crops including rice, onions, tomatoes and other vegetables.

\section{Major Livestock}

Reliable statistics on livestock holdings did not exist, but careful estimates suggested a total of 10 to 11 million cattle in the early 1970s. Although an epidemic of rinderpest killed more than a million cattle in 1983, production recovered by the end of the 1980s. The UN Food and Agriculture Organization estimated that in 1987 there were 12.2 million cattle, 13.2 million sheep, 26.0 million goats, 1.3 million pigs,
700,000 donkeys, 250,000 horses, 18,0000 camels found mostly in the Sahel savanna around Lake Chad, and 175 million poultry nationally, owned mostly by villages rather than by commercial operators. The livestock subsector accounted for about 2 percent of GDP in the 1980s (Metzi, 1991).

Until the 1990s, cattle-raising was limited largely to the northern fifth of the country that was free of the tsetse fly (Table 4). A program of tsetse-fly research and eradication was somewhat successful during the 1970s and 1980 s, but 90 percent of the national cattle herd was still found in the northern states in 1990. About 96 percent of these animals were zebutype cattle, most of which were tended by Fulani pastoralists. Traditionally, the Fulanis move their herds during the dry season to pasture in the more moist Guinea savanna, returning northwards when the rains began and danger from the tsetse fly increases. During the 1970s and 1980s, the expansion of cultivated areas and irrigation seriously obstructed this migration by cutting off access to usual travel routes.

Table 5: Comparison of Food Production, and Demand with Shortfalls and Imports (Million Mt)

\begin{tabular}{lllllllll}
\hline Description & $\mathbf{1 9 9 4}$ & $\mathbf{1 9 9 5}$ & $\mathbf{1 9 9 6}$ & $\mathbf{1 9 9 7}$ & $\mathbf{1 9 9 8}$ & $\mathbf{1 9 9 9}$ & $\mathbf{2 0 0 0}$ & $\mathbf{2 0 0 1}$ \\
\hline Production & 86.70 & 89.25 & 93.35 & 95.64 & 98.74 & 100.41 & 102.12 & $\mathbf{1 0 3 . 8 6}$ \\
Food demand & 87.23 & 89.55 & 96.26 & 99.03 & 101.87 & 104.63 & 107.46 & $\mathbf{1 1 0 . 3 7}$ \\
Shortfall surplus & 00.53 & 0.30 & 2.91 & 3.43 & 3.13 & 4.22 & 5.34 & $\mathbf{6 . 5 1}$ \\
Food import & $\mathbf{0 . 6 7}$ & $\mathbf{0 . 5 8}$ & $\mathbf{2 . 9 5}$ & $\mathbf{3 . 4 7}$ & $\mathbf{3 . 2 4}$ & $\mathbf{4 . 4 8}$ & $\mathbf{5 . 5 9}$ & $\mathbf{6 . 9 1}$ \\
\hline
\end{tabular}

(Source: FOS, Review of the Nigeria Economy, Various Issues)

Table 6: Mean values of properties with significant grazing effects, obtained from 16 samples

\begin{tabular}{llll}
\hline Soil properties & Ungrazed & Grazed & Percentage change \\
\hline Silt $(\%)$ & 11.31 & 8.75 & -23 \\
Macroporosity $(\%)$ & 20.51 & 12.39 & -40 \\
Total porosity $(\%)$ & 45.49 & 38.70 & -15 \\
Bulk density $\left(\right.$ gmcm $\left.^{-3}\right)$ & 1.46 & 1.65 & +13 \\
Hydraulic conductivity $\left(\mathrm{cmh}^{-}{ }^{1}\right)$ & 78.40 & 31.82 & -59 \\
\hline
\end{tabular}

Note : percentage change $=100$ (Ungrazed-grazed/grazed); (-) implies decease and (+)

implies increase in the grazed fields. Source: (Asadu, et al. 1999). 
Most of Nigeria's remaining cattle, 3 to 4 percent, are smaller than the zebu type and less valuable as draft animals. However, they possess a resistance to trypanosomiasis that makes it possible to raise them in the tsetse-infested humid forest zone (Table 4). The government improved these herds in early 1980 by importing breeding stock of a particularly disease-resistant strain from The Gambia.

Most of Nigeria's sheep and goats are reared in the north, where the Fulani maintained an approximate ratio of 30 percent sheep and goats to 70 percent cattle. About 40 percent of northern non-Fulani farming households are estimated to keep sheep and goats. Most pigs are raised in the south (Table 4), where the Muslim proscription against eating pork is not a significant factor.

Almost all rural households raise poultry as a subsistence meat, chicken are predominantly of indigenous origin, and there is some crossbreeding with foreign stock. Egg production is low. Private commercial poultry operations increased rapidly during the 1970s and 1980s near urban areas, providing a growing source of eggs for the cities.

\section{Food Supply Situation (Food Security)}

Food crops grown in the country are consumed in the country. The production does not meet even local demands especially in the case of rice. Generally, food supply in Nigeria has two phases. Food is usually more available and cheaper at the harvest season and more expensive at scarce period which often coincide with the time of planting of each crop. Nigeria is the world highest producer of yam and cassava in the world. Cassava is an important food security crop in the whole of sub-Saharan Africa (Nweke et al. 1999). This is because it grows fairly well in areas of adverse biospheric conditions unlike most crops. In Nigeria most families both in the rural and urban areas take one meal with cassava product as a component at least once a day. Compared to cassava, yam is more expensive but it has additional cultural values (Nweke et al. 1999).

As a result of its high prices, yam is eaten regularly only in families with above average income.
Food crops such as maize, sorghum, and millet face some competition with industrial uses especially by the brewing and feed manufacturing industries. This situation results to high prices of the crops which affects their purchase for direct consumption as food. In addition, farmers experience losses especially during the harvest period. The production of beans especially cowpea and pigeon pea which are the main sources of vegetable protein for the rural populace hardly meets one half of local demands. Thus, the prices of such beans are out of reach of common people.

By the early 1970s, as the general standard of living improved, the demand for meat in Nigeria exceeded the domestic supply. As a result, 30 to 40 percent of the beef consumed in Nigeria was imported from Niger, Chad, and other neighboring countries. In the mid-1970s, Nigeria began importing frozen beef in response to export restrictions initiated by The National Livestock Production Company established domestic commercial cattle ranches in the late 1970s, but with poor results. The situation presently is that animal protein supply is still far below local needs. Greater number of cattle, sheep and goat is still being imported from the northern fridge of Niger and Chad. Though local production of poultry seems to have increased due to the increase in the number of private poultry farms in the country, demands for both eggs and chicken meat are far above local production. Thus, they are very exorbitant for common people to afford.

Fish production is gaining some popularity in the country but the number and size of fish farms are far from what will make significant contribution to the protein needs of the country. Fish from natural waters is still far above that from farms.

\section{Evidence of Food insecurity in Nigeria}

Fundamentally, the objective of agriculture is to provide food security in any nation so that households should have access to good and nutritious food for healthy living in order to be healthy and create national wealth. 
Table 7: Effects of erosion on the fertility status of an ultisol in Nigeria

\begin{tabular}{lllll}
\hline Parameter & Soil depth $0-10 \mathrm{~cm}$ & \multicolumn{2}{l}{ Soil depth $10-40 \mathrm{~cm}$} \\
\hline & Eroded & Uneroded & Eroded & Uneroded \\
Organic matter $(\%)$ & 0.86 & $2.86^{* *}$ & 0.73 & $1.04^{*}$ \\
$\mathrm{pH}\left(1: 2.5 \mathrm{H}_{2} 0\right)$ & 4.4 & 5.1 & 4.6 & $5.0^{*}$ \\
Total N & 0.09 & $0.15^{* *}$ & 0.08 & $0.08 \mathrm{~ns}$ \\
Available P (Bray-1 ppm) & 9.6 & $16.0^{* *}$ & 12.0 & $12.3 \mathrm{~ns}$ \\
Exch. Cations, (meq/100g soil) & & & & \\
$\mathrm{Ca}$ & 1.7 & $3.2^{* *}$ & 1.6 & $2.8 \mathrm{~ns}$ \\
$\mathrm{Mg}$ & 1.1 & $1.9^{*}$ & 2.3 & $0.13 \mathrm{~ns}$ \\
$\mathrm{~K}$ & 0.15 & $0.35^{* *}$ & 0.11 & $7.3 \mathrm{~ns}$ \\
$\mathrm{CEC}($ meq/100g soil) & 6.5 & $10.4^{* *}$ & 6.9 & \\
\hline $\mathrm{ns},{ }^{* *},=$ not significant, significant at $5 \%$, and $1 \%$ probability levels respectively. Source: (Mbagwu, 1984$)$.
\end{tabular}

There is threat of hunger and poverty as $70 \%$ of the population live on less than N100 (US \$ 0.7) per day. Thus, access to adequate and nutritious food is limited by low income and poverty. The vulnerable and food insecure include the poor, smallholder farmers, children, pregnant women, lactating mothers and the elderly. It has been estimated that $\approx 60.8 \%$ Nigerians are malnourished (FOS undated).

The youths are unemployed and not many would want to take to agriculture. Those engaged in agriculture $(\approx 70 \%$ of the entire population) are becoming old and their production system is inefficient leading to regular shortfall in national domestic production. Food import is thus a common feature (Table 5).Domestic food production is on the increase but not enough to meet national food demand. Post harvest losses $(20-40 \%)$ also contribute to food shortages because harvesting, processing/ storage techniques are inefficient.

\section{Food Balance Sheet}

Table 5 shows domestic food production, demand and shortfalls between 1994 and 2001. It is clear that domestic production over the years had not met the demand. In fact the short fall had been on the increase since 1994. If nothing is done about the shortfalls soonest, it will be very difficult to manage. As net food importer presently, food production in Nigeria must grow consistently well above demand to bridge shortfalls. Agriculture deserves concessional support to raise output, and attain food security in the country.

\section{National Programmes Intended For Food Security Over The Years}

These programmes are just listed. A detailed analysis of the major programme is available (Asadu, 2002b). However, the common objective of all was to ensure adequate food security in the country but the current food situation in the country indicates that they have all failed. The common reason for their failure is poor implementation. i. Farm Settlement Programme (introduced late 1950s)

ii. Agricultural Development Projects (ADPs projects began in 1975)

iii. National Accelerated Food Production Programme(NAFPP), started in 1973 but extended to all states in 1977)

iv. Operation Feed the Nation (OFN, started in 1976)

v. River Basin Development Authority Programme (RBDA 1973-through 1979, law in 1976)

vi. Green Revolution Programme (GR) Part of Third Development Plan 1979

Vii. Directorate of Food, Roads and Rural Infrastructure (DFRRI Established in 1986)

viii National Agricultural Land Development Authority (NALDA- established in 1990 and late Rural Integrated Agricultural Development Programme (ADP)

ix. Agro Service Center Programme (ASC)

x. National Seed Service (NSS) $1975-1980$

xi. National and State Food Production Companies

xii. National Acceleration Crops Production Programme(NAICPP)- 1996

xiii. Agricultural and Rural Transformation Programme (ARTP) - 2000

xiv. National Economic Empowerment Development Strategy (NEEDS) was introduced in 2003/2004; it is a reform programme that encourages private sector operations.

xv. Presidential Initiative Programmes (being implemented within the framework of NEEDS.

\section{Major Problems/Issues And Challenges Funding Problem}

Poor funding of agriculture remains a major problem hindering agricultural development in the country. In addition funds meant for agriculture is often diverted into private hands. It common to find non-farmers getting loans meant 
for agriculture and diverting it to nonagricultural activities.

\section{Health Issues}

By 2003 it was estimated that HIV/AIDS claimed 310000 lives in the country and the adult prevalent rate was $5.4 \%$ while over 3.6 million people were having the disease. This scenario depletes the population that would have been engaged in agricultural production. Other prevalent

major infectious diseases of very high degree of risk most of which are food- or waterbornediseases are bacterial and protozoan diarrhea, hepatitis A, and typhoid fever. Prevalent deficiency diseases which may affect farmers' performances that are found in the country include

i. Iron deficiency, which affects physical capacity, and in severe cases lead to death and susceptibility to infections.

ii. Protein Energy Malnutrition (PEM), which causes growth failure in children, and weight loss in adults; Relationship exists between

PEM and infections like measles, diarrhea, whopping cough, tuberculosis, and malaria.

iii. Vitamin A, deficiency, which reduces resistance to infections.

Other diseases such as vector-borne disease eg. malaria and respiratory disease eg. Meningococcal meningitis as well as aerosolized dust or soil contact disease eg Lassa fever contribute significantly to low agricultural productivity in the country.

\section{Land Tenure System}

Traditional land tenure throughout Nigeria was based on customary laws under which land was considered a community property. This is the prevailing situation in spite of the Land Use Act that tends to give the government power to acquire land any where especially in the interest of the public. An individual has rights to the land he farms in his lineage or community area. He could possess the land as long as he used it to his family's or society's benefit, and could pass the land on to heirs and pledge its use to satisfy a debt.

The prevailing individual ownership of land leads to land fragmentation which reduces farm sizes and hinders mechanization of agriculture thereby limiting the use of land for commercial crop production. It can also lead to high cost of land or scarcity of land and force later generation to migrate out of their community. The abuse by land speculators is also possible

\section{Economic/policy issues}

In the late 1980s, Nigeria reduced the structural bias against agricultural activity by decontrolling farm prices, maintaining subsidies on fertilizer and farm exports as well as maintaining import bans on some food items. Despite the granting of increased incentives to the domestic farming industry, agricultural output rose slowly because of inadequate transportation and power networks, a lack of appropriate technology, and the ineffective application of rural credit. Although the domestic production of food did not decline, on a per capita basis, food is unavailable to the greater majority of the population. Several good agricultural policies failed on the account of poor implementation.

\section{Soil problems}

The finite nature of land resources implies that the increase in food production will have to continue to come from agricultural intensification and increases in crop and animal per unit area and per unit time from land already under cultivation (Lal, 2000). It has been shown that food security for an increasing population is largely a problem of good soil management on existing cultivated lands and this requires increased number of trained manpower besides the frequently mentioned and capital intensive fertilization, pesticide use and improved crop varieties (Yaalon and Arnold, 2000). The extensive analysis of work done in sub-Saharan Africa (SSA) including Nigeria shows that about $42 \%$ of the rain-fed cropped land in SSA have their major constraints to agricultural production related to low inherent soil fertility and nutrient imbalance while $36 \%$ have constraints related to sandy or stony texture (Lal, 2000). Other problems like soil erosion and desertification are also devastating in Nigeria.

The estimated agricultural productivity in SSA and for the entire continent showed that crop yield losses due to past (1960-1990) erosion ranged from $2-40 \%$ with a mean of $6.2 \%$ for SSA and $8.2 \%$ for the continent (Lal, 1995). The value for SSA was translated to mean non-production of about 3.6, 6.5 and 0.4 million tonnes of cereals, root and tubers and pulses respectively. Nigeria has very serious problems of soil degradation, declining yield and unprecedented rate of population growth and a sustainable management of soil and water resources has been recommended (Lal, 1990).

The major problems of agriculture in Nigeria which are related to land use have been summarized as follows (FDALR, 1996): human activities, such as indiscriminate bush clearing, felling of trees, bush burning, road construction and open cast mining; 
climatic factors such as high rainfall intensity and duration;

soil factors such as high erodibilty, texture and weak structure;

activities of animals such as overgrazing;

population pressure(put available land under stress);

ignorance on the part of land users leading to land misuse;

reluctance on the part of land users to embrace innovations;

bad cultivation practices, e.g. ridging along the slope.

\section{Illustrations Using Overgrazing and Erosion}

The consequences of overgrazing on the soil physical properties in southeastern Nigeria have been reported (Asadu, et al. 1999). The result of the study (Table 6) shows that the deterioration in soil physical properties in a period of $<15$ years of grazing ranged from about $15 \%$ in total porosity to $60 \%$ in hydraulic conductivity. Definitely the effect would be worse with chemical properties.

\section{Scars of Land Degradation by Erosion}

Soil erosion is the removal of soil materials from the land surface by water and/or wind at a rate in excess of that of addition by soil forming processes (FDALR, 1982). It is known that the contribution of erosion to soil loss is the most important in the country. The annual soil loss due to all forms of erosion in Nigeria (excluding tidal erosion) is estimated at 25 million tonnes per annum. A survey report estimated that 1.5 million ha-cm of agricultural land are washed away by rain alone while only slightly less than that quantity are blown by wind in Nigeria every year (Anande-Kur, 1987). Over 90\% of the land area of the country is plagued by one form of erosion or the other.

The overall effects of erosion on the fertility status (Table 7) shows that eroded soil had a lower fertility status than the uneroded soil, especially in the $0-10 \mathrm{~cm}$ depth (Mbagwu, 1984).. Erosion resulted in $38-70 \%$ reduction in the soil fertility indices assessed (Table 7). Earlier study in western Nigeria also showed that these nutrients and SOM were easily lost in both runoff water and eroded sediments; hence their lower contents on the eroded relative to the uneroded soils (Lal, 1974). Two other works found that loss of nutrients shows up most for nitrogen and phosphorus but will be significant with any nutrient associated with the cation exchange capacity (CEC) or soil organic matter (Stocking, 1987; (Ponzi, 1993).

\section{Soil Management For Sustainable Agriculture In Nigeria \\ Use of Organic Residue}

Organic manure often includes wastes from both plants and animals whether composted or fresh but intended for use in farming. They are often brought into the field from outside to improve both the soil physical and chemical fertility and enhance crop performance. The extent the manure can enhance soil nutrient content and physical properties of the soil depends on the source, quality and quantity of organic matter added. Organic manuring is an intensive practice and more common in farms around dwelling homes, market centres, and under continuous cultivation, hence the practice is limited in spread but can be sustainable.

The advantages of organic manure in improving the fertility of soils are however, well known. It has been found that the application of $5 \%$ poultry manure proved more effective in improving the productivity of an ultisol in Nigeria than a combination of 120, 30 and 120 kgha $^{-1}$ NPK respectively (Mba, 1983).. Also another work showed that poultry manure, compost manure, rice husk and saw dust used as amendments at the rate of $5 \%$ were more effective than a combination of high doses of NPK and $\mathrm{Mg}$ fertilizers in improving the productivity of acrisols in Nigeria (Mbagwu, 1984). The effectiveness of these organic amendments is directly proportional to their $\mathrm{C}$ : $\mathrm{N}$ and $\mathrm{C}$ : $\mathrm{P}$ ratios.

\section{Use of Cover Crops/Mulch}

Cover crops are integrated in different cropping systems: crop rotation, mixed cropping, relay cropping. In crop rotation the cover crop, which in most cases is a legume, occupies a specific plot for a given period usually a year or more before a follow up crop is planted in that plot. Mixed cropping involves growing two or more crops with different growth habits during one season e.g. Telferia with cassava or maize. When these crops are grown on ridges the cover crop can then be planted on the furrows between the ridges. Relay cropping is a system where the second crop is planted between the rows of already growing crops. It may also refer to the introduction of a crop just before the previous crop is harvested so that the soil is almost under cover throughout the season. The later crop may be the cover crop and timing of its planting is usually before rains start to cause serious losses through erosion and leaching processes. Basically the cover crops provide protective cover against soil erosion and also help to reduce the rate of soil moisture loss through reduced evaporation from the soil surface. Mixed cropping is more popular in southern than in 
northern Nigeria, even in southeastern Nigeria most $(80 \%)$ of the farmers grow their crops in mixtures (Okorji, 1986). It has been shown (Table 4) that soil splash under cassava can be drastically reduced when grown in mixture with sweet potato (Ipomoea batata) and maize (Zea mays) (Lal, 1985).

A work done on an alfisol in Nigeria showed that cover crops could be used to improve SOM, total N, CEC, and infiltration rate and water retention capacity (Lal, and Couper 1990). Cover crops also tend to lower the bulk density of the soil. Some of the cover crops used include Paspalum notatum and Cynodon alenfuensis as grasses; Peuraria phaseoloides, Stylosanthes guinensis, Centrosema pubescens and Mucuna utilis as legumes. Some of the legumes and tress can fix large amounts of biological nitrogen, for instance, Lucerne can fix $300-400 \mathrm{kgha}^{-1} \mathrm{~N}$ annually and similar results have been obtained in the parts of the humid tropics (Lal and Couper, 1990).

Mulching involves the use of organic or artificial materials to cover seedbeds when the crops have been planted. Mulch tillage is a system whereby crops such as maize, wheat, and sorghum are harvested and the crop residues are left on the surface (stubble mulching) or partly worked into the soil (thrash farming). Mulching has the advantages of reducing the rate of soil water evaporation, the direct impact of solar energy (temperature moderation), weed growth and competition with crops. The mulching of yam mounds planted during the dry season is very commonly practiced in yam-growing areas of the country (Asadu, 1989).

\section{Use of Green Manure}

This is a system where a cover crop usually a legume is grown purposely for its manorial value. It is grown and ploughed into the soil while still green. It decays to improve both the physical and chemical properties of the soil. In addition it helps to protect the soil from erosion. This is unlike some grasses eg. vetiver which is grown purposely for erosion control. Though green manuring is not yet widely practiced owing to labour and cost constraints, this practice needs to be encouraged especially in the highly degraded soils.

\section{Fallow Systems}

Greenland (1978) categorizes the fallow systems as shifting cultivation (long fallow), recurrent cultivation (short fallow) and continuous cultivation (no fallow). More specifically long fallow has been described as $<10 y e a r s$ of continuous cultivation followed by 10 or more years of fallow; short fallow as $<10$ years of continuous cultivation and $<10$ years of fallow; and continuous cultivation as at least 10 years of cultivation with less than one year of fallow between crops (Asadu and Nweke. 1999).

Shifting cultivation and bush fallowing are the natural responses to land use on the poor soils. The classical work on shifting cultivation showed that an ecological balance of nutrients and SOM can be achieved and the system can be quite efficient in the forest zone (Nye and Greenland. 1960). However, it been reported that a ratio of between 3 and 6 years' fallow to 1 year of cultivation is sufficient in the rainforest environment to maintain SOM at $75 \%$ of its original level (Young, 1979). The savannas are less efficient regenerators, requiring between 1020 years for 1 cultivation. However, the fallow system other than the continuous cultivation, which is synonymous with agricultural intensification, can no longer support the everincreasing population. Thus, the sustainability of those systems that cannot support the increasing population is in question.

\section{Tillage Systems}

A runoff study in Nigeria showed that runoff was highest on the bare fallow followed by the ploughed plots then by plots under traditional mounds and lowest on untilled plots (Bernard, M; Lal and Schwertman,. 1985). Except for the no-tillage system, erosion was reduced on the plots that were cultivated across slope. Studies (Ohiri, and Ezuma, 1990) in Nigeria under (a) conventional practice (ploughing to a depth of $20 \mathrm{~cm}$ followed by harrowing and ridging), (b) minimum tillage (digger-made holes about $20 \mathrm{~cm}$ in depth at $1 \mathrm{~m} \mathrm{x}$ $1 \mathrm{~m}$ spacing) and (c) no tillage (pushing the sharp end of cassava cuttings directly into the soil at an angle of $45^{\circ}$ ), showed that significantly higher moisture $(\mathrm{p}=0.01)$ were obtained in the reduced tillage systems compared with conventional practices. The work also revealed that the effects of reduced tillage systems on organic carbon content after 2 years of cultivation decreased the initial value for the system. The reduction due to conventional tillage was $32 \%$. When tillage was performed, the amount of organic matter exposed to oxidation was high throughout the ploughed layer, and consequently, it was more easily depleted. This is because with reduced tillage, only a relatively small amount is exposed to oxidation, and depletion occurs at or near the soil surface (Doran, 1980).

\section{Slash And Burn Technique}

Clearing and burning are some of the techniques the farmers use to incorporate into the soil some of the materials accumulated in the vegetative cover during fallow. Even though most of the 
nitrogen, sulfur and carbon are lost as gasses, the plant ash contains elements such as $\mathrm{Ca}, \mathrm{Mg}, \mathrm{K}$, $\mathrm{Na}$, etc, which are added to the soil and the soil $\mathrm{pH}$, is often remarkably improved. Burning leads to an initial decrease in the population of soil microorganisms, which later develops to levels greater than before especially in the case of forest. In the case of savanna, the fire has little effect on the microbial population. It has been reported that in SSA (including Nigeria) available $\mathrm{P}, \mathrm{Ca}, \mathrm{Mg}$, total exchangeable bases and ECEC were significantly higher in fields where bush burning had been in practice for 1115 years than in other fields where it was not practiced (Asadu and Nweke, 1999.

\section{Livestock Grazing}

Livestock grazing involves grazing the fields with such farm animals as sheep, goat and cattle. This is often done before planting of the crops if it is envisaged as a soil fertility management practice.

The soil fertility value of livestock grazing is in the difference between the droppings and the vegetation removed. It has been observed that livestock such as cattle, sheep and particularly goats were frequently the cause of erosion if their number in a given area was not controlled (Datiri, 1974). Similarly The restorative effect of grazed pasture is questionable, especially if the stocking rate is not controlled (Lal and Couper 1990). With the stocking rate of 4-8 cattle per ha, soil compaction was more severe in grazed pastures than with no-till maize-cowpea rotation. That was evidenced from the depressed grain yield of maize and cowpea when grown in rotation with grazed pasture. Uncontrolled and intensive grazing has also been reported to affect the physical properties of the soils of eastern Nigeria (Asadu, et al. 1999). However, it has been observed that if grazing is well managed, it has the potential of improving the available soil $\mathrm{P}$ content, $\mathrm{pH}$, and base saturation (Asadu and Nweke. 1999).

\section{Use of Soil Amendments}

The soil amendments considered here are mineral and organic fertilizers and lime. The potential use of mineral fertilizers to improve the productivity of tropical soils has been elaborately investigated in Nigeria. However, the emphasis on the studies has been more on the type rather than on the source of the fertilizers (Mbagwu, 1984). The foci have been also on the replacement of major nutrients like NPK lost through run-off, leaching and crop removal. The effectiveness of the fertilizers has shown to be both soil- and crop dependent. The same work (Mbagwu, 1984) also illustrates that high doses of $\mathrm{N}$ and $\mathrm{P}$ were able to restore the productivity of an eroded alfisol (luvisol) to the original topsoil level in southeastern Nigeria. However, liberal doses of mineral fertilizer alone were found to be inadequate for restoring the productivity of an eroded acrisol. It was also shown that a combination of NPK fertilizer mixture with 250 tha $^{-1}$ of organic manure was superior to the use of inorganic fertilizer alone in improving soil productivity.

\section{Agroforestry and Alley Cropping.}

Agroforestry is an important component in farming systems in the humid tropics not only in terms of nutrient recycling and soil conservation but also in supplying food and firewood to the small farmers and ensuring overall sustainability of production (CGIAR, 1989). Basically both practices involve the growing of shrubs and trees that can help to improve soil fertility either through the return of organic matter in their leaves or through nitrogen fixation. The selected plants are usually fast growing and examples are neem (Azadirachta indica) and Eucalyptus camaldulensis, Acioa barterii, Alchornea cordifolia, Glyricidia sepium and Leucaena leucocephala. They are also grown in belts across the direction of the prevailing winds in order to check wind erosion. When they are grown in alleys (rows) with crops planted in between them the system is referred to as alley cropping. In Nigeria it has been shown that using alley cropping, the yield of cowpea obtained in three years was supportive of the practice of the system (Lal, and Couper 1990). Their findings showed that cowpea yield increased from $397 \mathrm{kgha}^{-}{ }^{1}$ in 1995 through 602 $\mathrm{kgha}^{-1}$ in 1996 to $615 \mathrm{kgha}^{-1}$ in 1997 . The use of Glyricidia and Leuceaena (Table 5) hedgerows under maize in an Alfisol in Nigeria resulted in reduced runoff and soil erosion. Depending on the spacing, more than $40 \%$ reduction is possible with Glyricidia while Leuceaena is less efficient but can give rise to a reduction of up to $7 \%$.

\section{Contour Tillage and Ridging}

This is practiced in areas of rugged topography in the country. The practice consists of ploughing the land on or close to the contour. Each furrow acts as a small dam, slowing down the movement of water over the soil. This is more effective when the land is newly cultivated but has the disadvantages of the ridges breaking down quickly and therefore may not be effective over a long period of time.

Contour bunds or banks are small bunds usually $20-45 \mathrm{~cm}$ high and built along the contour. They are built with the idea of catching and retaining the runoff water and allowing it to infiltrate slowly into the soil. Banks of this type can only be used effectively when the infiltration 
rate of the soil is high and the rainfall intensities are relatively low, because if one bank overflows and breaks, the whole system can fail causing more erosion damage. For greater effectiveness, contour banks are sometimes combined with contour cultivation, the latter helping to reduce the quantity of runoff.

\section{Future Prospects}

Generally agricultural sustainability refers to the successful management of resources for agriculture to satisfy changing human needs while maintaining or enhancing the quality of the environment and conserving natural resources (CGIAR, 1989). The prospects of sustainable agricultural development and provision of adequate food in Nigeria can only be described as bright from the available suitable biophysical environment in Nigeria. Nigeria has abundant uncultivated arable land and range fields, favourable climate and large work force. The resources that can also be mobilized such as funds for credit and purchase of inputs are also available if the three tiers of government of the day are willing to release such funds. Experts with research capabilities that can realize agricultural sustainability in Nigeria are abundant in universities and research institutes. They need support and encouragement from the government.

\section{Policy and Extension}

A policy is a deliberate plan of action to guide decisions and achieve rational outcomes. It is also a guideline consisting of principles and rules governing the behaviour of persons in an organization. Policies prescribe how people in an organization should behave (Asiabaka, 2002). Policy can also be seen as a form of directed action which indicates as clearly as possible what one wants to achieve, how one can want to do it, and how much time will be taken to achieve the set goals.

Agricultural extension is a service or system which assists farm people through educational procedures, improved farming methods and techniques, increased production efficiency and income, better their levels of living and lift the social and educational standards of rural life (.Maunder,1973). Agricultural extension is fundamental in the transformation process of agricultural production activities (Ani, 2007). The extension function is crucial for sustainable agricultural development. Agricultural extension brings about changes through education and communication in farmers' attitude, knowledge and skills (Koyenikan, 2008). The role of agricultural extension involves dissemination of information; building capacity of farmers through the use of a variety of communication methods and help farmers make informed decisions. Help in extension is similar to empowering all members of the farm households to ensure holistic development (Sinkaiye, 2005). Modern agricultural extension system encourages the development of positive attitude in the scientists to appreciate the knowledge, experiences and capabilities of the local people.

Extension policy is a subset of the broader agricultural policy (Naswem, et al, 2008). In 2001 a new Nigerian agricultural policy was launched. Some broad objectives of the new policy include:

1) Promotion of the increased application of modern technology to agricultural production.

2) Improvement in the quality of life of rural farmers among other objectives ((FMARD, 2001.

Agricultural extension was addressed under service delivery activities. Since agricultural extension is essential in technology dissemination, all the three tiers of government in Nigeria are involved in jointly financing agricultural extension delivery and monitoring its impact. Also, according to the policy, extension service delivery will be streamlined through the integration of ADP and state extension services for greater effectiveness. To achieve this, various agricultural delivery approaches have been evolved and tried in Nigeria over the years. It was not unusual to find more than one system being employed at the same time within the country. Such extension delivery approaches include:

Ministry of agriculture-operated extension services

Co-operative extension service

Commodity board extension services

Farmers and community Association extension services.

Agricultural training institutions

Training and visit extension model

Non-governmental organization model.

In addition to these general extension duties in the country, such programmes like the farm settlement scheme, operation feed the nation, School- to-land programmes etc were all launched and implemented at various times ((FMARD, 2001).

However, in 1986 the federal government decided to reform the extension system in order to establish an effective professional agricultural extension service. Consequently, the training and visit $(\mathrm{T} \& \mathrm{~V})$ system of agricultural extension was chosen and adopted. The practice of $\mathrm{T} \& \mathrm{~V}$ involves.

An agreed technical package or message for each time period over a season taught to subject matter specialists (SMS) by research personnel 
in a monthly 2-day (MTRMS) training meetings and in turn, taught to extension agents by the subject matter specialists in fortnightly training (FNT) sessions.

a) An organized fortnightly visit of extension agents to specific contact farmers as representatives of their community.

b) Set-up demonstration plots (Small Plot Adoption Technique, SPAT), established by contact farmers themselves to be used to teach messages or technologies to non-contact farmers or 'contact' farmers' neighbours.

The agricultural development programmes (ADPs) in Nigeria have been modeled after the Training and Visit extension system. The role of training is essential in helping to overcome cultural differences and in facilitating information exchange. Each participant has something to teach the other. Training sessions and workshops (such as the fortnightly, FNT and monthly training review meetings-MTRM) being organized by the Nigerian Agricultural Development Programme are occasions for creating and developing synergy between the participants, with the ultimate goal being to raise the rural farmers level of professionalism. In doing so, they may take greater responsibility and become more autonomous in the decision-making process for the management of their rural activities.

In summary, the main function of agricultural extension is to disseminate useful and technical information to farmers. Over the years, different extension approaches have been used to reach the target farmers. Nigeria has never had an extension policy that has been promulgated by the legislature (or even military government) assigning explicit mandate and providing a clear direction for the development and execution of extension programmes. Extension has not been treated on its own merit but as an appendage of agricultural policy, which in any case is not directed by a clear policy. The only scenario that looked like an extension policy was the adoption of ADP system using T and V approach. Since extension policy is a subset of the agricultural policy, it then follows that a properly articulated agricultural policy should support a viable extension policy. Therefore a sound extension policy is necessary to achieve success in transferring knowledge and inculcating skills and positive attitude to farmers.

\section{CONCLUSION}

The situation of agricultural production in Nigeria is a pitiable one. The country is blessed with favourable biophysical environment which can ensure self-sufficiency in food and raw materials production with excess for export. Arable land, good climate, expert and abundant labour, and funds are sufficiently available in the country but the government is paying lipservices to the sector. This attitude portends a bleak future for agriculture, food security and the entire country.

\section{REFERENCES}

Akamigbo, F.O.R. 1999. Land capability classification as a tool for effective land use policy', in Employing an Effective Agricultural Land Use Policy for Nigeria. Proceedings of the National Seminar on Land Use Policy and Practice. Ibadan, 19-23 July, 1998.

Anande-Kur, S. 1987. Keeping the land alive: A keynote address delivered at the workshop on soil productivity- the of agricultural productivity. University of Jos, Markurdi, June 1987

Ani, A.O. 2007. Agricultural extension. A pathway for sustainable agricultural development. Apani publications: Kaduna.

Asiabaka, C.C. 2002. Agricultural extension: A handbook for development practitioners .Omoku, River state: Molsystem United services.

Asadu, C.L.A. 1989. A comparative study and evaluation of yam-zone soils and the performance of six cultivars of white yam (D. rotundata) in southeastern Nigeria:. Ph.D Thesis University of Nigeria, Nsukka, Nigeria.

Asadu C.L.A 2002 . Fluctuations in the characteristics of an important short tropical season, 'august break' in eastern Nigeria. Discovery and Innovation. 14 (1\&2): 92-101

Asadu, C.L.A. 2002. State policies in agriculture. Journal of Economic, Social and Cultural Rights 1(6) : 27-58.

Asadu C.L.A. and F.I Nweke. 1999. Soil of Arable Crop Fields in sub-Saharan Africa: Focus on cassava-growing Areas. Collaborative study of cassava in Africa working paper No 18. IITA, Ibadan, Nigeria.

Asadu, C.L.A., O.O. Ike and B.O. Ugwoke. 1999. Cattle grazing and environment in eastern Nigeria: Impact on soil physical properties. Outlook on Agriculture 28:8791.

Asadu, C. L. A., P. I. Ezeaku and G. U. Nnaji. 2004. Land use and soil management situations in Nigeria: An analytical review of changes. Outlook on Agriculture 33:27-37. UK 
.Bernard, M; Lal R. and U. Schwertman. 1985. Soil and water conservation effectiveness of different cultural practices. Farming Systems Program annual Report. IITA, Ibadan, Nigeria.

.CGIAR (Consultative Group on International Agricultural Rsearch), 1989. Sustainable agricultural production: implications for international agricultural research. FAO Research and Technology Paper 4, Rome, Italy.

Datiri, B.T. 1974. Soil and Water Conservation Practices particularly in areas of shifting Cultivation. In: Pp77-80 Report on the FAO/SIDA/ARCN Regional Seminar on Shifting Cultivation and Soil Conservation in Africa held at the University of Ibadan, Nigeria. 2-21 July. FAO, Rome, Italy.

Doran, D. 1980 'Soil microbial and biochemical changes associated with reduced tillage', Soil Science Society of American Journal 44 : 765-777.

Federal Department of Agricultural Land Resources (FDALR, 1982), 'Land evaluation for agricultural land use in Nigeria,' in Efficient Use of Nigeria Land Resources, Proceedings of the first National Seminar on Agricultural Land Resources, Kaduna, 13-18 September. 1982

Federal Department of Agricultural Land Resources (FDALR, 1996), Assessment of Land and Vegetation Changes in Nigeria between 1976/78 and 1993/95, Federal Department of Forestry, Abuja, Nigeria.

Federal Ministry of Agriculture and Rural Development (FMARD). 2001. The New Policy Thrust. Federal Ministry of Agriculture and Rural Development. Abuja, Nigeria

Food and Agriculture Organization (FAO ,1976). A framework for land evaluation', FAO Soil Bulletin No 32, FAO, Rome.

Foth, D. H. and J. W Schafer. 1980. Soil Geography and Land use. John Wiley and Sons, Inc. New York USA.

Federal Office of Statistics (FOS undated). Review of the Nigeria Economy, Various Issues 1994- 2001, Federal Government of Nigeria, Abuja, Nigeria Greenland, D.J. 1978. The responsibilities of Soil Science. Intern. Soil Sci. Soc. $11^{\text {th }}$ Congress. Edmonton, Canada 2: 341-359.
Koyenikan, M.J. 2008.Issues for Agricultural extension policy in Nigeria. Journal of Agricultural Extension 12 : 52-62.

Lal, R. 1985. Research achievements towards soil and water conservation in the tropics. Potential and priorities,' in Soil Conservation and Productivity,' Proceedings IV International Conference on Soil Conservation (I. Pla Sentis ed.), Maracay, Venezuela Nov 3-9, 1985, , pp 755-787.

Lal, R. 1974. No-tillage effects on soil properties and maize production in western Nigeria. Plant and Soil 40: 589-606.

Lal, R. 1990. Low -resource agriculture alternatives in sub-Saharan Africa. J. Soil Water Conser. 45: 437-445.

Lal, R. 1995. Erosion crop productivity relationships for soils of Africa. Soil Sci. Soc. Amer. J. 59: 661-667.

Lal, R. 2000. Soil management in the developing world. Soil Sci. 165:57-72.

Lal, R. and D.C Couper 1990. Soil microvariability. In: Soils of the Humid Tropics. US National research Council, National Academy of Sciences, Washington D.C. pp45-49.

Mba, N. 1983. Evaluations of the effectiveness of various soil amendments in the improvement of sub soil productivity. B. Agric (Soil Sci.) thesis, University of Nigeria, Nsukka.

Mbagwu, J.S.C. 1984. Effects of artificial desurfacing of Alfisols and Ultisols in southern Nigeria. 11. Changes in soil physical properties. Soil Sci. Soc. Amer. J. 48: 831-834.

Mbagwu, J.S.C. 1988. Physico-chemical properties and productivity of an ultisol in Nigeria as affected by long term erosion. Pedologie XXXVIII :137-154.

Maunder, A.H. 1973. Agricultural extension: A reference; manual (Abridged version) FAO, Rome, Italy.

Metzi. R. 1991 Geography Guide, Sign up for my Newsletter, My Blog, My Forum, Sponsored Links Vsat Nigeria Satellite broadband $\mathrm{Ku} \& \mathrm{C}$ band Unrivaled service \& prices.www.LinkSystemsuk.Com

Naswem, A.A., Daudu, S and Ejembi, E.P. 2008 Legislated policy as the basic for effective extension delivery: Lesson from the United Kingdom. Journal of Agricultural Extension.12:1-8.

Nweke, F.I., B.O.Ugwu, A.G.O. Dixon, C.L.A. Asadu and O. Ajobo. 1999. Cassava Production in Nigeria: A function of Farmer Access to Markets and to 
Improved Production and Processing Technologies. COSCA Working Paper No.20.Collaborative Study of Cassava in Africa, IITA, Ibadan, Nigeria

.Nye, P.H. and D.J. Greenland. 1960. The soil under shifting cultivation Commonwealth Bureau of Soils Technical Communication No. 51.

Ohiri, A.C and H.C. Ezumah. 1990. Tillage effects on cassava (Manihot esculenta) production and some soil properties. Soils \& Tillage Research 17: 221-229.

Okorji, E.C. 1986. Productivity of yam under alternative cropping systems adopted by small-holder farmers of southeastern Nigeria. Agricultural Systems 22: 231241.

Ponzi, D. 1993 Soil erosion and productivity. A brief review, Desertification Bulletin, No 22.

Rosenberg, M. 2005. Nigeria Information | CIA Factbook | World Atlas Home hll://geography.about.com/mbiopage

Sinkaiye, T. 2005. Agricultural extension: participatory methodologies and approaches in Agricultural extension in Nigeria. S.F. Afolayan (ed) Ilorin. AESON: 220-233 www. monster. ca assessed on 23/05/08.

Stocking, M. 1987. Tropical red Soils. Fertility Management and Degradation. The red soils of east and southern Africa. Proceedings of an Intern. Symposium. IDRC-MR. Harare, Zimbabwe, 24-27 Feb. 1986.

United States Department of Agriculture (USDA) 1998. Soil taxonomy: A basic system for making and interpreting soil surveys. Soil Conservation Service, Agricultural Handbook No.436. US Department of Agriculture. US Government Printing Office, Washington DC.

Yaalon, D.H. and R.W. Arnold. 2000. Attitudes towards soils and their societal relevance: then and now. Soil Sci. 165: 5-12.

Young, A. 1979. The nature and management of the proper tropical latosols. Outlook on Agriculture 10: 27-32 